\title{
Zha Jianying, Tide Players
}

New York, The New Press, 2011, 228 pp.

Jean-François Huchet

Translator. N. Jayaram

\section{(2) OpenEdition}

\section{Journals}

\section{Electronic version}

URL: http://journals.openedition.org/chinaperspectives/5834

DOI: 10.4000/chinaperspectives.5834

ISSN: 1996-4617

\section{Publisher}

Centre d'étude français sur la Chine contemporaine

\section{Printed version}

Date of publication: 30 March 2012

Number of pages: $77-78$

ISSN: 2070-3449

\section{Electronic reference}

Jean-François Huchet, «Zha Jianying, Tide Players », China Perspectives [Online], 2012/1 | 2012, Online since 30 March 2012, connection on 22 September 2020. URL : http://journals.openedition.org/ chinaperspectives/5834; DOI : https://doi.org/10.4000/chinaperspectives.5834

This text was automatically generated on 22 September 2020.

(c) All rights reserved 


\title{
Zha Jianying, Tide Players
}

\author{
New York, The New Press, 2011, 228 pp.
}

\section{Jean-François Huchet}

Translation : N. Jayaram

1 With detailed portraits of seven Chinese a woman and six men - Zha Jianying presents a rich and nuanced canvas of urban China's evolution since the early 1970s. It must be noted at the outset that this is not an academic tome; nevertheless, the book is far from superficial. Among the plethora of academic works being published on China today, many fail to deliver the kind of account of change in Chinese society that this book does. It is not Zha's first such effort either. Her 八十年代 (Bashi niandai, The 1980s), published in 2006, presented a picture of artists, intellectuals, and researchers during that decade and met with major success, to the extent of being named in China one of the most important books of the decade in 2010.

2 "Focus on the Chinese to explain China,"

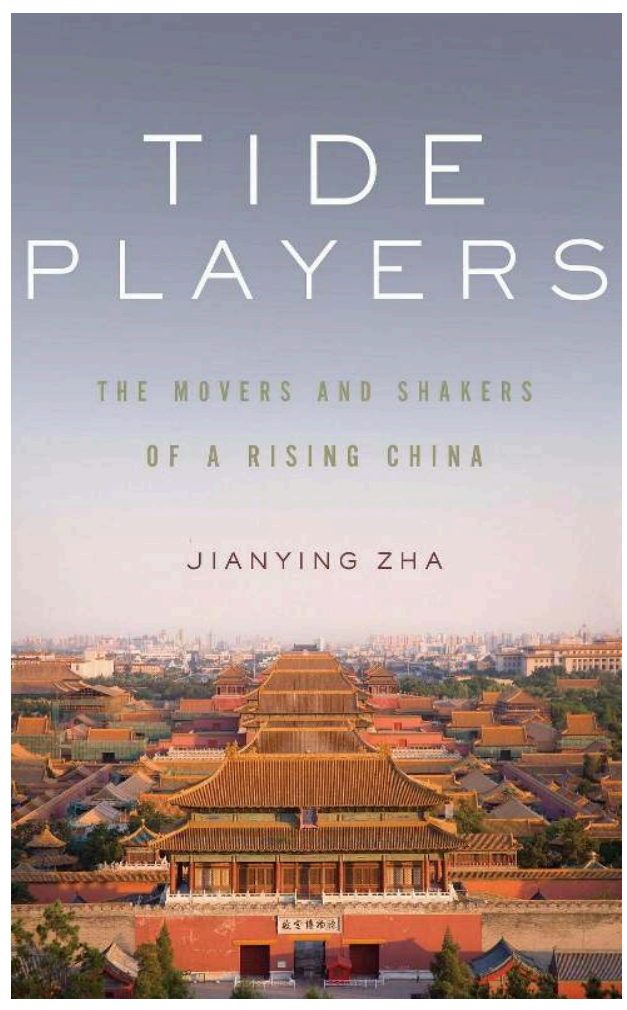
says the author in her introduction (p. 10). Indeed, but which individuals are to be relied on to best embody China's history of the past 40 years? It was no simple choice, and as the author notes, China is too big for just one author. It was therefore preferable to focus on people one knew best. And so she chose those from the pre-1978 generation who had had a taste of Mao-era China. The four entrepreneurs and three intellectuals Zha looks at in her book are all public personalities who at one time or 
other "made headline news." From household appliance magnate Zhang Dazhong to property tycoon Pan Shiyi as well as Peking University vice-president Zhang Weiying, the book sheds highly contrasting light on many facets of change in China over four decades.

The author deserves particular praise for not having avoided writing about those close to her: her brother Zha Jianguo, ${ }^{1}$ a dissident; Sun Lizhe, a "barefoot" capitalist and university classmate; and the late 1980 sulture minister Wang Meng, whom she met in the early 1990s. Far from painting just flattering portraits, the author used her intimate knowledge of the personalities to describe their personal motivations and contradictions, as well as their courage, most tactfully linking them to the functioning of the political system and society. She presents, for instance, a nuanced portrait of Wang Meng as a man of letters and "servant of the state." Zha was taking on a difficult exercise, as Wang had been the target of barbs from all sides - from intellectuals for his continued service to the state through the 1989 political crisis as well as from Party apparatchiks for having refused to pay homage to "fallen soldiers during the fight to restore order" in June that year. Zha tackles the subject with her own assessments and expressions of irritation with the "state servant," only to gradually mollify her judgment along with her increasing friendship with him. Without shedding her critical stance, she ends her account of Wang by recognising in this controversial public figure a certain coherence of action and personality towards a political regime that had claimed his entire career. It was her more intimate knowledge of the man that helped her perceive this coherence and understand some of the choices he made. Such nuance and absence of definitive judgments on personalities are to be found in all the portraits, be they of entrepreneurs who amassed much wealth or of her brother who chose the path of dissidence. Through these portraits, she seems to indirectly pose a question to Western readers: How exactly would you have behaved in these situations and under such a harsh political system? Her portraits amount to as many responses to this question. Some chose to rebel against the political system and risked being crushed by it; others sought to influence it from the inside, laying themselves open to being condemned as collaborators; and yet others abandoned politics altogether at the end of the Cultural Revolution or of the 1989 student movement, plunging headlong into business.

4 Nevertheless, even in the case of the entrepreneurs Zha has described, politics and memory are never far away. Despite their personal material affluence, which could have helped expel the memory of past difficulties, the Mao-era privations and humiliations keep rising to the surface and influencing current events. Such is the case with Zhang Dazhong, the affluent entrepreneur who dominated China's household appliance sector until his recent sale of his company at a premium. Despite his business acumen, Zhang was long at pains to rehabilitate the reputation of his mother, who was persecuted during the Cultural Revolution. He held Mao in such deep disdain that he sometimes publicly questioned the official Chinese history since the Communist takeover. In her own way, property developer Zhang Xing, who with her husband Pan Shiyi became rich and famous by building the Soho complex in Beijing, frequently refers to her years of penury and of work in a factory during her youth in Hong Kong. In her conversations with Zha, she harks back to the importance of having discovered Western-style politics during her studies in England and then, later, in the 1989 student movement. From all the personalities covered in Zha's book, the impression that emerges is that they lived several lives in one, but that they fell back on their own 
resources to cope psychologically with their memory and the pace of change they orchestrated in their lives. Some succeeded better than others.

In general, and this is one of the book's strengths, the author has superbly managed to enmesh China's larger history into individual life stories. Although she does not say so clearly in her introduction, Zha Jianying sought to avoid a "top-down" approach to history, that of viewing events merely through the prism of changes in Party politics. Some personalities, such as entrepreneurs, plunged headlong on the paths the Party opened up; others, such as her brother, resisted by forming a political party; but all were vectors of change that caught the Party off guard. While most "surfed" the reform wave created by Deng Xiaoping in 1978, all contributed in their own ways to influencing an autonomous evolution in society, the economy, and perhaps in some respects politics as well.

One of the lacunae that may be pointed out in the book is that it could have done with two or three more portraits to complete the picture of post-Mao urban China. In her introduction, Zha defends her decision not to have attempted descriptions of those she is ill acquainted with, such as migrants, farmers, and workers. Surreptitious observation would not have helped her deliver the finesse and the nuances of personalities distilled into her book. Seeing how the portraits have turned out, it is just as well that she did not attempt it. Nevertheless, it would have been good to have had more women in addition to Zhang Xing. Then again, the current mix may reflect something deeper about contemporary male-dominated China. Ditto for the absence of younger people: they appear in the background, especially in the portrait of the entrepreneur Zhang Dazhong, who forced his young assistants to read Jung Chang's account of $\mathrm{Mao}^{2}$ in order to open their eyes to the reality of Chinese politics. Again, the book would have been more representative had it included a young person of the postCultural Revolution generation.

\section{NOTES}

1. Also published in The New Yorker, 23 April 2007, pp. 46-57.

2. Jung Chang and Jon Halliday, Mao: The Unknown Story, New York, Knopf, 2005, 814 pp.

\section{AUTHORS}

JEAN-FRANÇOIS HUCHET

University professor, INALCO-Langues'O, Paris. 